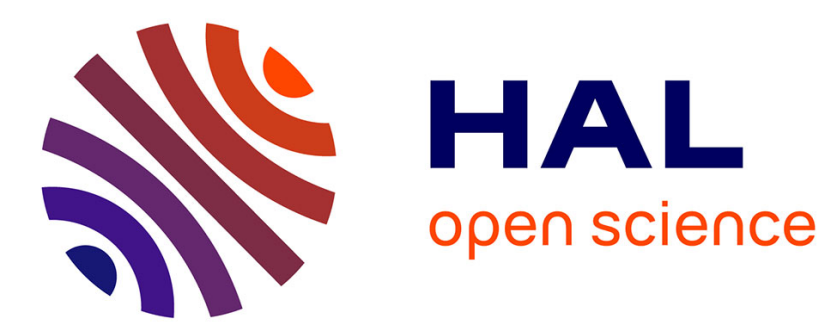

\title{
High-pressure synthesis and structural behavior of sodium orthonitrate $\mathrm{Na} 3 \mathrm{NO} 4$
}

\author{
Raul Quesada Cabrera, Andrea Sella, Edward Bailey, Olivier Leynaud, Paul
} F. Mcmillan

\section{- To cite this version:}

Raul Quesada Cabrera, Andrea Sella, Edward Bailey, Olivier Leynaud, Paul F. Mcmillan. Highpressure synthesis and structural behavior of sodium orthonitrate Na3NO4. Journal of Solid State Chemistry, 2011, 184 (4), pp.915-920. 10.1016/j.jssc.2011.02.013 . hal-00993061

\section{HAL Id: hal-00993061 https://hal.science/hal-00993061}

Submitted on 19 May 2014

HAL is a multi-disciplinary open access archive for the deposit and dissemination of scientific research documents, whether they are published or not. The documents may come from teaching and research institutions in France or abroad, or from public or private research centers.
L'archive ouverte pluridisciplinaire HAL, est destinée au dépôt et à la diffusion de documents scientifiques de niveau recherche, publiés ou non, émanant des établissements d'enseignement et de recherche français ou étrangers, des laboratoires publics ou privés. 


\title{
High-Pressure Synthesis and Behaviour of Sodium Orthonitrate $\mathrm{Na}_{3} \mathrm{NO}_{4}$
}

\author{
R. Quesada Cabrera ${ }^{\mathrm{a}}$, A. Sella ${ }^{\mathrm{a}}$, E. Bailey ${ }^{\mathrm{a}}$, O. Leynaud ${ }^{\mathrm{b}}$, P.F. McMillan ${ }^{\mathrm{a}, *}$ \\ ${ }^{a}$ Department of Chemistry and Materials Chemistry Centre, Christopher Ingold Laboratories, \\ University College London, 20 Gordon Street, London WC1H OAJ, United Kingdom \\ ${ }^{b}$ Department of Crystallography, Birkbeck College, Malet Street, London WC1E 7HX, United \\ Kingdom
}

*Corresponding author. Fax:+442076797463.

E-mail address: p.f.mcmillan@ucl.ac.uk (P.F.McMillan).

\begin{abstract}
Sodium orthonitrate $\left(\mathrm{Na}_{3} \mathrm{NO}_{4}\right)$ can be prepared rapidly and in high yield from $\mathrm{NaNO}_{3}$ and $\mathrm{Na}_{2} \mathrm{O}$ at high pressure in a multianvil press. The acceleration is atributed to a substantially negative molar volume of reaction, and provides a much faster route compared to the synthesis at ambient pressure. The high-pressure behaviour of sodium orthonitrate has been studied in a diamond anvil cell up to $64 \mathrm{GPa}$. At the upper end of the pressure ranges we see evidence for incipient pressure-induced amorphization. Similar processes are also discussed for $\mathrm{Na}_{2} \mathrm{O}$ and $\mathrm{NaNO}_{3}$.
\end{abstract}

\section{Keywords}

Sodium orthonitrate; sodium oxide; sodium nitrate; high-pressure synthesis; diamond anvil cell; pressure-induced amorphization.

\section{Introduction}

Structures based on tetrahedrally-bonded oxoanions form a wide range of important minerals and materials including sulphates, phosphates, and especially the orthosilicates ,containing isolated $\mathrm{SiO}_{4}{ }^{4-}$, groups that are major components of the Earth's upper mantle. Such silicate anions are well known to polymerize to form chains, sheets, and threedimensional network structures. The high-pressure behaviour of these tetrahedrally coordinated species has been studied extensively because of density-driven transitions to higher coordinated structures that are important for mantle mineralogy. For example, $(\mathrm{Mg}$, $\mathrm{Fe})_{2} \mathrm{SiO}_{4}$ olivines transform to spinel structures containing silicon in octahedral coordination and this marks the passage between the upper and lower mantle within the Earth. Octahedrally coordinated silicon also occurs in other high-pressure mantle minerals including silicate perovskite, ilmenite, and garnet structures and $\mathrm{SiO}_{2}$ polymorph stishovite. Unusual five-fold coordinated silicate species have been identified in glasses prepared at high pressure and these play an important role in the densification and viscous flow of the molten materials [1]. Compression of $(\mathrm{Mg}, \mathrm{Fe})_{2} \mathrm{SiO}_{4}$ crystals and glasses results in pressure-induced amorphization and formation of such highly-coordinated species and linkages between the orthosilicate anions.

It is notable that tetrahedral oxoanion species are generally formed with atoms of the second or higher rows of the periodic table ( $\mathrm{Si}, \mathrm{P}, \mathrm{S}, \mathrm{Cl}, \mathrm{Ge}, \mathrm{As}$ etc). By contrast, the first row elements tend to form trigonal species $\left(\mathrm{BO}_{3}{ }^{3-}, \mathrm{CO}_{3}{ }^{2-}, \mathrm{NO}_{3}{ }^{-}\right)$, behaviour attributed to their small size and to somewhat nebulous ideas such as octet expansion related to orbital 
energies. However, a tetrahedral oxoanion chemistry does occur for boron, either copolymerized with other species or as isolated $\mathrm{B}(\mathrm{OH})_{4}{ }^{-}$anions (e.g., $\left.\mathrm{LiB}(\mathrm{OH})_{4}\right)$. A longstanding question in solid state chemistry and geochemistry has therefore been whether structures based on tetrahedral $\mathrm{NO}_{4}{ }^{3-}$ or $\mathrm{CO}_{4}{ }^{4-}$ units can be prepared at all, and the extent of their thermodynamic or indeed kinetic stability. The occurrence of tetrahedral orthocarbonate species would have implications for carbon storage within mineral or melt species within the Earth.

$A b$ initio cluster calculations have indicated that tetrahedral units based on light element species should be thermodynamically stable with respect to decomposition to simpler ions [2]. For carbon, unambiguous proof of such structures has remained elusive. A tetrahedrally-bonded structure analogous to the $\mathrm{SiO}_{2}$ polymorphs, was observed by high$\mathrm{P}, \mathrm{T}$ synthesis from $\mathrm{CO}_{2}$ [3]. Other high-P,T studies on $\mathrm{CO}_{2}$ have indicated formation of glassy "carbonia" that could contain even higher-coordinated carbonate species [4]. Recent experiments found that $\mathrm{MCO}_{3}(\mathrm{M}=\mathrm{Sr}$, Ca) can be transformed into polymeric chain structures containing linked $\mathrm{CO}_{4}$ tetrahedra at high pressure [5]. Ionic orthocarbonate species containing $\mathrm{CO}_{4}{ }^{4-}$ groups have not been synthesized yet. Nonetheless, theoretical calculations [6] indicate that a very low energy barrier hinders the orthocarbonate structure from being a global minimum and molar volume considerations suggest the synthesis via high-pressure conditions, due to the smaller volume of the orthocarbonate structure as compared to the carbonate and oxide precursors mixture.

For nitrogen on the other hand, the first solid-state orthonitrate was synthesised by Jansen [7], who obtained sodium orthonitrate $\mathrm{Na}_{3} \mathrm{NO}_{4}$ containing isolated $\mathrm{NO}_{4}{ }^{3-}$ units, by reaction of $\mathrm{Na}_{2} \mathrm{O}$ with $\mathrm{NaNO}_{3}$ at high temperature over a period of months (Fig. 1). This compound is therefore an attractive testing ground to explore the stability of high coordinate structures under extreme conditions.

In the present study, we have synthesized $\mathrm{Na}_{3} \mathrm{NO}_{4}$ via high-pressure conditions and investigated the high-pressure behaviour of $\mathrm{Na}_{3} \mathrm{NO}_{4}$ using synchrotron X-ray diffraction and Raman spectroscopy in the diamond anvil cell (DAC).
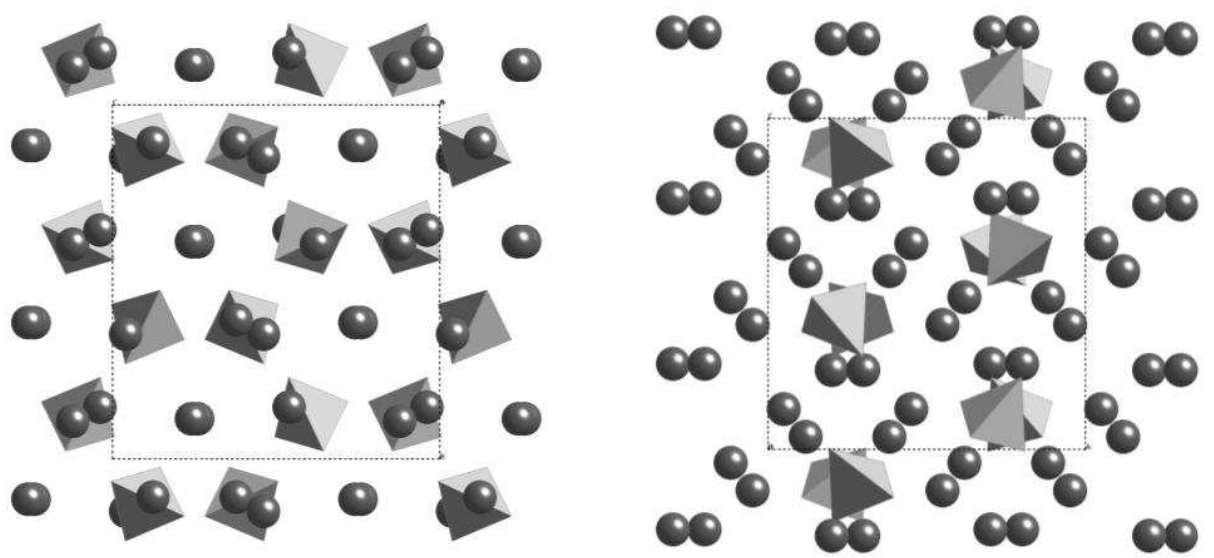

Fig. 1. Two views of the orthorhombic $(P b c a) \mathrm{Na}_{3} \mathrm{NO}_{4}$ structure reported in ref. [3] at ambient conditions. View along $a$ (left) and $b$ axes (right). The $\mathrm{NO}_{4}{ }^{3-}$ groups are indicated by filled tetrahedra surrounded by $\mathrm{Na}^{+}$ ions (circles). 


\section{Experimental}

The ambient pressure synthesis of $\mathrm{Na}_{3} \mathrm{NO}_{4}$ was conducted by reaction between $\mathrm{Na}_{2} \mathrm{O}$ and $\mathrm{NaNO}_{3}$ as described in ref. [7]. The reactants $\left(\mathrm{Na}_{2} \mathrm{O} 80 \%\right.$, Aldrich, main impurity $\mathrm{Na}_{2} \mathrm{O}_{2}$; $\mathrm{NaNO}_{3} 99.9 \%$, Aldrich) were ground together in an approximately 3:1 ratio under dry box conditions ( $<10$ ppm $\mathrm{O}_{2} / \mathrm{H}_{2} \mathrm{O}, \mathrm{N}_{2}$ atmosphere) and loaded into a silver capsule that was crimped shut then transferred to a glass tube and sealed under vacuum before heating in a furnace at $380{ }^{\circ} \mathrm{C}\left(10{ }^{\circ} \mathrm{C} \mathrm{h}^{-1}\right)$ for periods between 14-90 days.

For in situ high-pressure Raman and synchrotron XRD experiments, $\mathrm{Na}_{3} \mathrm{NO}_{4}$ samples were loaded into a screw-driven DAC without any pressure-transmitting medium under $\mathrm{N}_{2}$ or $\mathrm{Ar}$ glove box conditions $\left(\mathrm{H}_{2} \mathrm{O} / \mathrm{O}_{2}<10 \mathrm{ppm}\right)$. Diamond culet diameters were 300-150 $\mu \mathrm{m}$. Preindented rhenium gaskets were drilled with $80-\mu \mathrm{m}$ diameter holes. Ruby chips were added to estimate the pressure inside the sample chamber [8].

The home-built Raman system is based on Kaiser supernotch filters, an Acton spectrograph and a $\mathrm{LN}_{2}$ cooled back-thinned CCD detector [Soignard, Chem Mater]. An $\mathrm{Ar}^{+}$laser $(514.5 \mathrm{~nm}, \sim 1 \mathrm{~mW}$ entering the cell) was focused onto the sample using a $50 \mathrm{x}$ Mitutoyo objective and Raman scattering was collected using backscattering geometry. Angle-dispersive X-ray diffraction data were obtained at station 9.5 HPHT, Daresbury SRS using $\lambda=0.444 \AA$. Two-dimensional X-ray patterns were obtained and then integrated around the diffraction rings and converted into 1D plots using FIT2D software [9]. The Xray beam was collimated and focused to $30 \mu \mathrm{m}$ inside the cell using a Laue optical system [10]. Additional X-ray diffraction data were obtained at ESRF BM01A (Swiss-Norwegian beam Lines) using angle-dispersive techniques $(\lambda=0.7 \AA)$.

\section{Results and Discussion}

High-Pressure Synthesis of $\mathrm{Na}_{3} \mathrm{NO}_{4}$ from $\mathrm{Na}_{2} \mathrm{O}+\mathrm{NaNO}_{3}$ : characterisation by $\mathrm{X}$-ray diffraction and Raman spectroscopy

The synthesis of $\mathrm{Na}_{3} \mathrm{NO}_{4}$ at room pressure allows the detection of $\mathrm{Na}_{3} \mathrm{NO}_{4}$ traces after 7-14 days [7]. According to these authors, a single crystal can be obtained only after 240 days. After several attempts, we obtained nearly pure $\mathrm{Na}_{3} \mathrm{NO}_{4}$ samples only after 90 days (Fig. 2). The main impurity was excess $\mathrm{Na}_{2} \mathrm{O}$, but traces of $\mathrm{Na}_{2} \mathrm{O}_{2}$ were sometimes detected by Raman spectroscopy. Runs carried out on samples containing $\mathrm{Na}_{2} \mathrm{O}$ and $\mathrm{NaNO}_{3}$ impurities allowed the X-ray patterns and Raman spectra of this antifluorite-structured compound to be obtained for the first time at high pressure. 


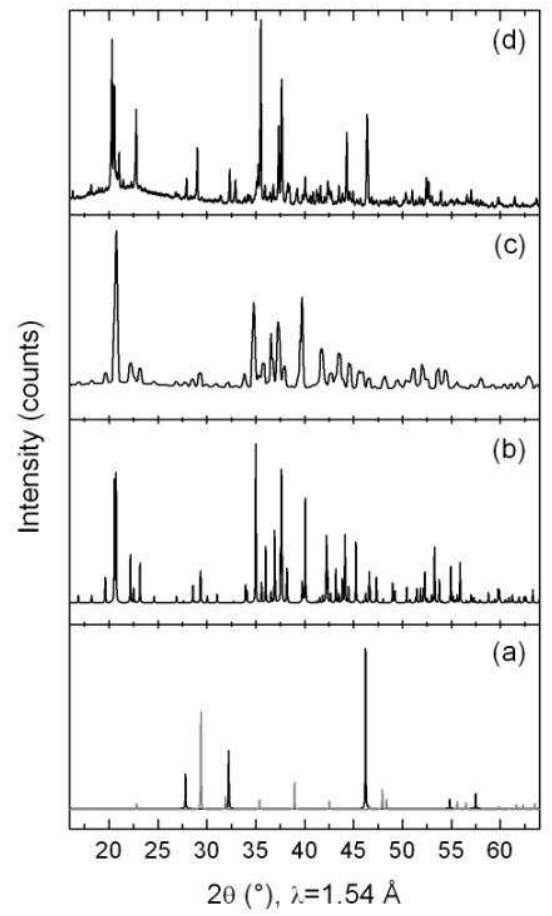

Fig. 2 - Powder X-ray diffraction patterns at ambient P,T conditions from (a) precursors mixture, $\mathrm{Na}_{2} \mathrm{O}$ (black) and $\mathrm{NaNO}_{3}$ (grey), (b) calculated $\mathrm{Na}_{3} \mathrm{NO}_{4}$ from ref. [7], (c) pure $\mathrm{Na}_{3} \mathrm{NO}_{4}$ found after synthesis at $380^{\circ} \mathrm{C} / 90$ days at room pressure, (d) $\mathrm{Na}_{3} \mathrm{NO}_{4}$ after synthesis in the multianvil cell at $4 \mathrm{GPa} / 500^{\circ} \mathrm{C} / 2$ days. The pattern shown in (c) was obtained using $\lambda=0.7 \AA$ at BM01A, the Swiss-Norwegian Beam Lines (ESRF) but with $2 \theta$ values re-

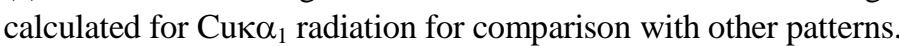

The precursors mixture $\left(3: 1\right.$ molar ratio, $\left.\sim 5 \mathrm{~mm}^{3}\right)$ was sealed inside a Pt capsule in the glove box and pressurized up to $4 \mathrm{GPa}$ in a 1,000-ton Walker-type multianvil press (Fig. 3). $\mathrm{W} / \mathrm{Re}$ thermocouples were used for temperature measurement and control. Then, the mixture was heated up to $500{ }^{\circ} \mathrm{C}\left(10{ }^{\circ} \mathrm{C} \mathrm{h}^{-1}\right)$ and held for 50 hours before quenching by turning off the furnace power.

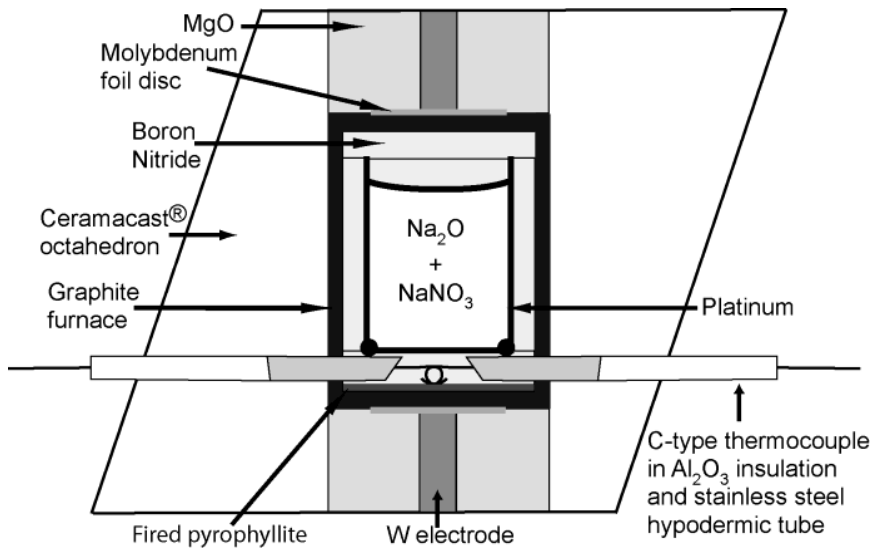

Fig. 3. Multianvil assembly. The capsule containing the precursors mixture was sealed by welding at one end, with a combination of $\mathrm{Pt}$ disc and BN plug at the other. This allowed easy loading in the glove box. The Pt disc had a slightly larger diameter than the capsule and was bowed slightly before assembly. Careful assembly produced gas tight sample environments without the need for welding at both ends. This greatly facilitates loading of temperature and atmosphere sensitive samples. 
Simple molar volume considerations for the reaction:

$$
\mathrm{Na}_{2} \mathrm{O}+\mathrm{NaNO}_{3} \rightarrow \mathrm{Na}_{3} \mathrm{NO}_{4}
$$

$\left(\mathrm{Na}_{3} \mathrm{NO}_{4}\left(V_{m}=57.20 \mathrm{~cm}^{3} \mathrm{~mol}^{-1}\right), \mathrm{Na}_{2} \mathrm{O}\left(V_{m}=27.31 \mathrm{~cm}^{3} \mathrm{~mol}^{-1}\right.\right.$ and $\mathrm{NaNO}_{3}\left(V_{m}=36.95 \mathrm{~cm}^{3}\right.$ $\left.\mathrm{mol}^{-1}\right)$ suggest a significantly negative value volume of reaction $(\Delta \mathrm{V}=-7.06)$ associated with the reaction. Hence the equilibrium is strongly shifted in favour of orthonitrate at high pressure. This is also reflected in the rate of the reaction - peaks associated with $\mathrm{Na}_{3} \mathrm{NO}_{4}$ could be seen within 2 days at $500^{\circ} \mathrm{C}$ (Fig. 2). Thus the application of pressure provides a useful route to the orthonitrate material.

The presence of $\mathrm{Na}_{3} \mathrm{NO}_{4}$ following syntheses at ambient and high pressure was first observed by Raman spectroscopy (Fig. 4). The Raman spectrum of $\mathrm{Na}_{3} \mathrm{NO}_{4}$ at room conditions is dominated by a strong peak at $843 \mathrm{~cm}^{-1}\left(v_{1}\right)$ due to symmetric $\mathrm{NO}_{4}{ }^{3-}$ stretching vibrations. The antisymmetric $\mathrm{N}-\mathrm{O}$ stretching bands are observed at $\sim 1000 \mathrm{~cm}^{-1}$ $\left(v_{3}\right)$. Symmetric and antisymmetric $\mathrm{O}-\mathrm{N}-\mathrm{O}$ bending modes appear between $650-670 \mathrm{~cm}^{-1}$ $\left(v_{4}\right)$ and at $540 \mathrm{~cm}^{-1}\left(v_{2}\right)$, respectively [7]. The Raman studies also demonstrate the presence of $\mathrm{Na}_{2} \mathrm{O}$ and $\mathrm{NaNO}_{3}$ remaining within the samples. The band at $240 \mathrm{~cm}^{-1}$ corresponds to the triply degenerate stretching mode of $\mathrm{Na}_{2} \mathrm{O}$, whereas the band at 1058 $\mathrm{cm}^{-1}$ along with a shoulder at $1067 \mathrm{~cm}^{-1}$ are due to the dominant $\mathrm{NO}_{3}$ stretching vibrations of $\mathrm{NaNO}_{3}$ (Fig. 4).

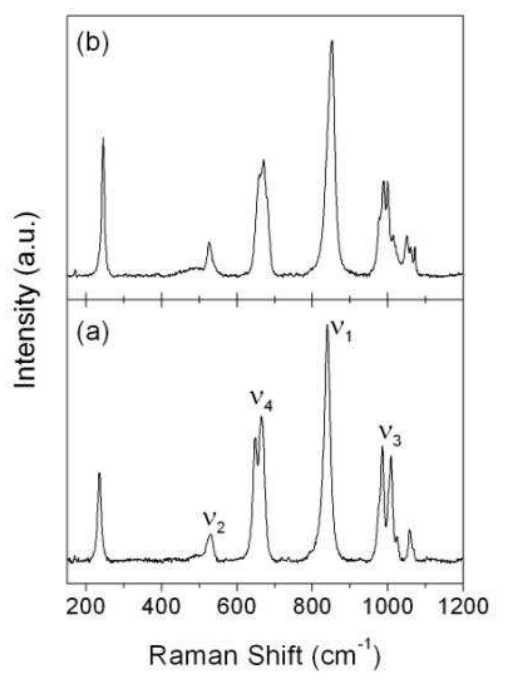

Fig. 4 - Raman spectra of $\mathrm{Na}_{3} \mathrm{NO}_{4}$ at ambient conditions after synthesis at (a) $380^{\circ} \mathrm{C} / 90$ days at room pressure and (b) $4 \mathrm{GPa} / 500^{\circ} \mathrm{C} / 2$ days. The corresponding vibrational modes are indicated [7]; the extra bands indicate the presence of precursors, $\mathrm{Na}_{2} \mathrm{O}$ and $\mathrm{NaNO}_{3}$.

\section{Raman spectroscopy at high pressure}

The high-pressure behaviour of $\mathrm{Na}_{3} \mathrm{NO}_{4}$ was monitored by Raman spectroscopy up to 61 $\mathrm{GPa}$ (Fig. 5). Using our microbeam technique (3-4 $\mu \mathrm{m}$ ) we could obtain spectra of $\mathrm{Na}_{3} \mathrm{NO}_{4}$ alone from regions where $\mathrm{Na}_{2} \mathrm{O}$ or $\mathrm{NaNO}_{3}$ grains were absent. Little change was observed in the $\mathrm{Na}_{3} \mathrm{NO}_{4}$ spectrum throughout the pressure range studied, indicating that the orthonitrate structure is remarkably resistant to compression. The vibrational frequencies plotted versus pressure show that a new band is clearly observed among the $v_{4}$ bending modes above $21 \mathrm{GPa}$ (Fig. 5), which indicates minor structural changes occurring within 
this pressure range. Compression above $40 \mathrm{GPa}$ results in the appearance of additional weak spectral features in the region between $300-450 \mathrm{~cm}^{-1}$. However, all these spectral changes are fully reversible upon decompression at room temperature.

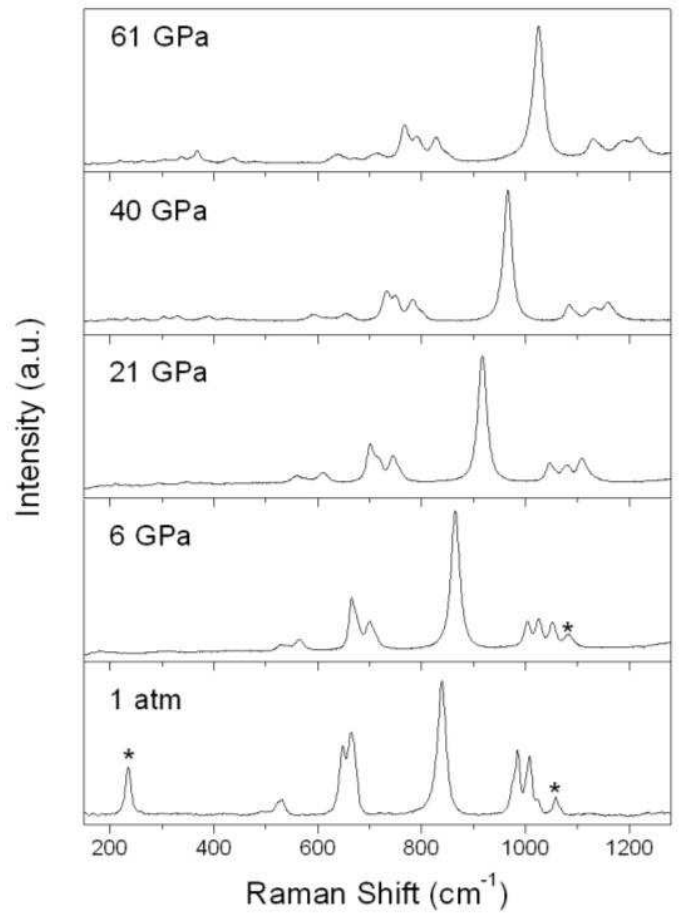

Fig. 5 - Raman spectra of $\mathrm{Na}_{3} \mathrm{NO}_{4}$ during compression at room temperature. We typically avoided those regions contaminated with any precursor in this study, but illustrate in some spectra the presence of $\mathrm{Na}_{2} \mathrm{O}$ and $\mathrm{NaNO}_{3}$ in the sample (symbols).

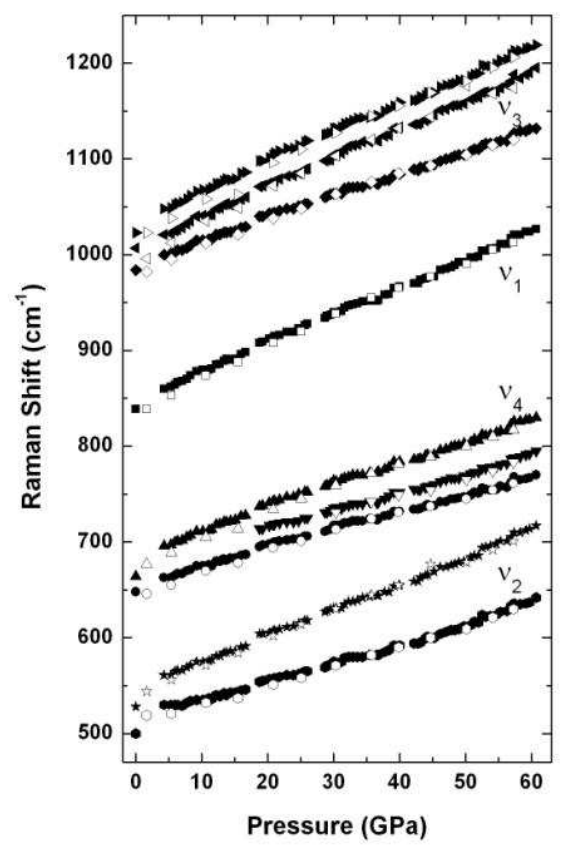

Fig. 6 - Raman shifts of $\mathrm{Na}_{3} \mathrm{NO}_{4}$ during compression (full circles) and decompression (empty circles) runs. All pressure-induced changes were found to be fully reversible. 
The X-ray diffraction experiments sampled a much larger volume of the material within the DAC compared with the microbeam Raman results described above. The X-ray beam could only be collimated to $30 \mu \mathrm{m}$ and the diameter of the DAC gasket hole was $\sim 80 \mu \mathrm{m}$, so features from $\mathrm{Na}_{2} \mathrm{O}$ and $\mathrm{NaNO}_{3}$ were present along with the $\mathrm{Na}_{3} \mathrm{NO}_{4}$ reflections in the patterns and these had to be taken into account during the analysis of the data. The diffraction patterns are dominated by $\mathrm{Na}_{2} \mathrm{O}$ reflections. The absence of a pressuretransmitting medium meant that compression was non-hydrostatic and peak broadening for all phases was expected to occur arising from pressure gradients and internal strains in the sample. Selected X-ray diffraction patterns of the reaction components upon compression are shown in Fig. 7.

There are no significant changes between the patterns recorded at 7 and $10 \mathrm{GPa}$, except for an intensity increase of the $\mathrm{NaNO}_{3}$ peaks, which reflects the inhomogeneity across the sample (Fig. 7). However, a closer observation of intensity ratios suggest that the peak at $2 \theta \sim 10.3^{\circ}$ may arise from a superposition of reflections from $\mathrm{NaNO}_{3}$ and $\mathrm{Na}_{3} \mathrm{NO}_{4}$, as it can be confirmed in the diffraction pattern obtained at $13 \mathrm{GPa}$. Indeed, above $10 \mathrm{GPa}$ reflections associated with $\mathrm{Na}_{2} \mathrm{O}$ broadened and vanished while a broad signal was observed at $2 \theta \sim 13.5^{\circ}$. The $\mathrm{NaNO}_{3}$ features also seem to undergo dramatic peak broadening and intensity decrease. The broadening and vanishing of the peaks from the precursors mixture will be discussed below. The peak at $10.3^{\circ}$ in the pattern at $13 \mathrm{GPa}$ must now correspond to the [023] reflection from $\mathrm{Na}_{3} \mathrm{NO}_{4}$ as its intensity is comparable with other peaks from the ambient-pressure structure (Fig. 7).

A minor rearrangement of the $\mathrm{Na}_{3} \mathrm{NO}_{4}$ structure seem to occur between 13-25 GPa, as suggested by the changes observed within the $11-13^{\circ}$ region of the corresponding patterns (Fig. 7). This is consistent with our Raman results (Fig. 6). Unfortunately, the broadening of the peaks was so severe as to preclude structure solution for any possible high-pressure modification.

Beyond $25 \mathrm{GPa}$, the diffraction patterns are dominated by the broad peak due to $\mathrm{Na}_{2} \mathrm{O}$. However, the $\mathrm{Na}_{3} \mathrm{NO}_{4}$ diffraction peaks are still visible up to $64 \mathrm{GPa}$ although they are significantly broadened, that might be due to the non-hydrostatic pressurization conditions, or could indicate the initial steps of some disordering mechanism operating at higher pressure. 


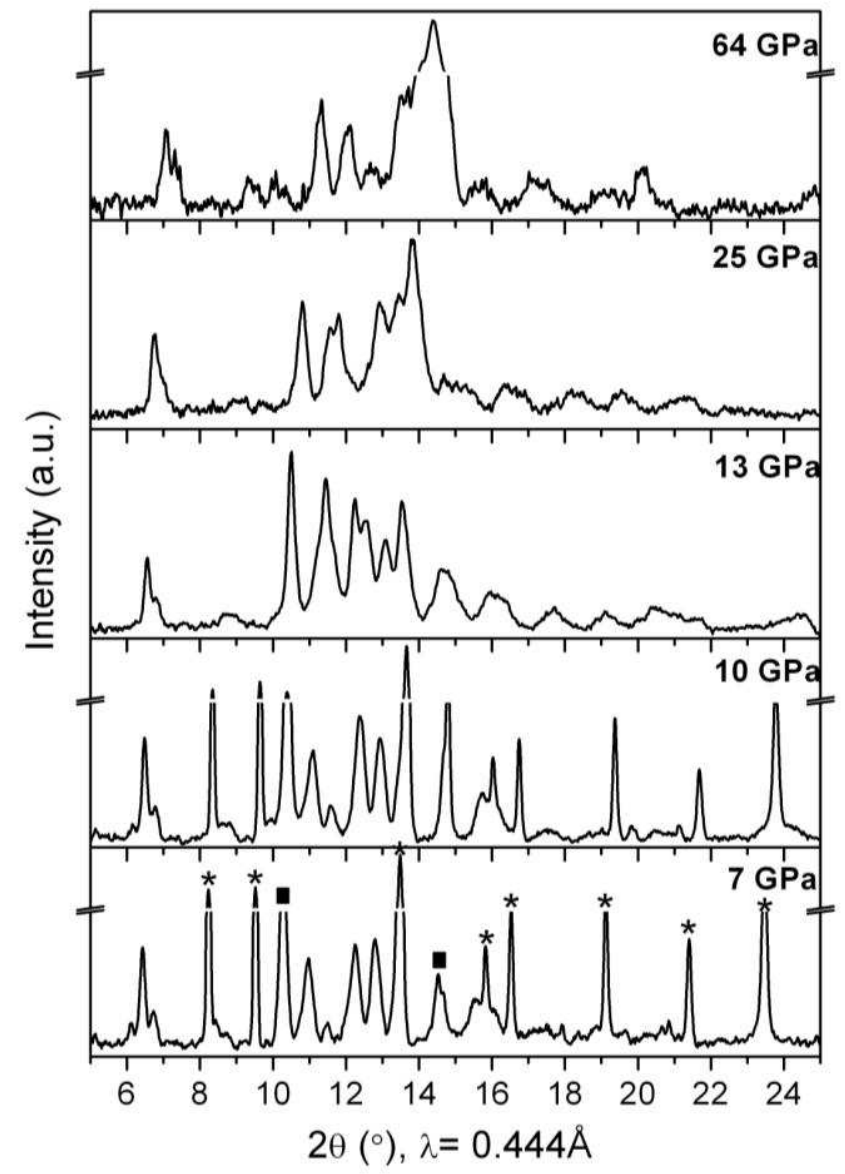

Fig. 7. Powder X-ray diffraction patterns from $\mathrm{Na}_{3} \mathrm{NO}_{4}$ upon pressure under non-hydrostatic conditions. The symbols mark those reflections corresponding to $\mathrm{NaNO}_{3}(\mathbf{\square})$ and $\mathrm{Na}_{2} \mathrm{O}(\uparrow)$.

The broadening and/or vanishing of those reflections due to the precursors may seem to contradict theoretical studies on alkaline oxides predict a very rich landscape for pressureinduced phase transitions in pure $\mathrm{Na}_{2} \mathrm{O}$ [11] or experimental observations in which pure $\mathrm{NaNO}_{3}$ remained crystalline beyond the pressure range observed in this work [12]. However, it is plausible that both compounds undergo pressure-induced amorphization due to geometrical instability in the mixture. The reduced diffusion of atoms in the mixture at high pressure may hinder the rearrangement of the corresponding structures into new crystalline phases, and thus a phase transition would be kinetically impeded. This is consistent with the pressure-induced amorphization process observed for $\mathrm{Ca}\left(\mathrm{NO}_{3}\right)_{2} / \mathrm{NaNO}_{3}$ mixture above $9 \mathrm{GPa}[13]$.

\section{Conclusion}

We saw no evidence for pressure-induced amorphization or appearance of new bands that might signal a coordination increase or polymerization among the orthonitrate groups within the pressure range studied. On the other hand, the broadening or vanishing of precursor peaks above $13 \mathrm{GPa}$ have been explained in terms of pressure-induced amorphization in the sample mixture, as a consequence of a possible kinetically-hindered phase transition. 


\section{Acknowledgements}

Fellowship details. We thank Alistair Lennie, 9.5 HPHT, SRS (now at Diamond Light Source) for his support during the diffraction runs and the Swiss-Norwegian Beam Lines (BM01A) for the pattern of the sample at room conditions.

\section{References}

[1] Stebbins J. F., McMillan P. F. and Dingwell D. B. (Editors), Structure, Dynamics and Properties of Silicate Melts, Vol. 32 of Reviews in Mineralogy (Mineralogical Society of America) 1995; X. Xue, M. Kanzaki, R.G. Tronnes, J.F. Stebbins, Science 245 (1989) 962-964.

[2] A.C. Hess, P.F. McMillan, M. O'Keeffe, J. Phys. Chem. 92 (1988) 1785-1791.

[3] V. Iota, C.S. Yoo, H. Cynn, Science 283 (1999) 1510-1513; M. Santoro, J-f. Lin, Hk. Mao, R.J. Hemley, J. Chem. Phys. 121 (2004) 2780-2787.

[4] M. Santoro, F.A. Gorelli, R. Bini, G. Ruocco, S. Scandolo, W.A. Crichton, Nature 441 (2006) 857-860.

[5] S. Ono, M. Shirasaka, T. Kikegawa, Y. Ohishi, Phys Chem Minerals 32 (2005) 8-12.

[6] M. Al-Shemali, A.I. Boldyrev, J. Phys. Chem. A 106 (2002) 8951-8954.

[7] M. Jansen, Z. Anorg. Allg. Chem. 491 (1982) 175-183.

[8] R.A. Forman, G.J. Piermarini, J.D. Barnett, S. Block, Science, New Series 176 (1972) 284-285.

[9] A.P. Hammersley, S.O. Svensson, M. Hanfland, A.N. Fitch, D. Häusermann, High Pressure Res. 14 (1996) 235-248.

[10] A.R. Lennie, D. Laundy, M.A. Roberts, G. Bushnell-Wye, J. Synchrotron Rad. 14 (2007) 433-438.

[11] Z. Cancarevic, J.C. Schön, M. Jansen, Phys. Rev. B 73 (2006) 224114-1/18

[12] J.C. Jamieson, A.W. Lawson, J. Appl. Phys. 33 (1962) 776-780; D.D. Klug, E. Whalley, Rev. Sci. Instrum. 54 (1983) 1205-1208.

[13] R.R. Winters, G.C. Serghiou, W.S. Hammack, Phys. Rev. B 46 (1992) 2792-2797. 